\title{
Lean Principles: An Innovative Approach for Achieving Sustainability in the Egyptian Construction Industry
}

\author{
Ayman A. E. Othman \\ Architectural Engineering \\ Department, Faculty of \\ Engineering, The British \\ University in Egypt (BUE), \\ El Shorouk, Cairo, Egypt \\ ayman.othman@bue.edu.eg
}

DOI 10.5592/otmcj.2014.1.2

Research paper

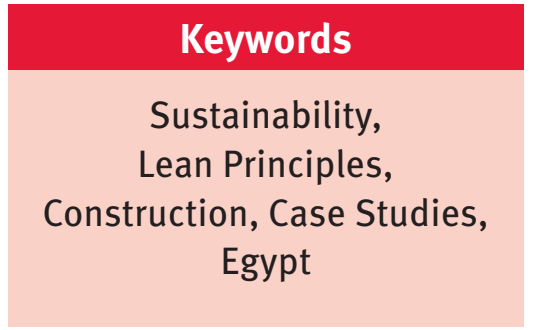

\author{
Mayar A. Ghaly \\ Architectural Engineering \\ Department, Faculty of \\ Engineering, The British \\ University in Egypt (BUE), \\ El Shorouk, Cairo, Egypt \\ jspmayar283@hotmail.com
}

\author{
Nazirah Zainul Abidin \\ School of Housing, Building \\ and Planning, University \\ Sains Malaysia, USM 11800 \\ Penang, Malaysia \\ nazirah_za@usm.my
}

IN SPITE OF THE ECONOMIC AND SOCIAL CONTRIBUTIONS OF THE CONSTRUCTION INDUSTRY (CI) IN TERMS OF ACHIEVING NATIONAL AND INTERNATIONAL DEVELOPMENT PLANS, OFFERING EMPLOYMENT OPPORTUNITIES, INCREASING GROSS DOMESTIC PRODUCT (GDP) AS WELL AS PROVIDING COMMUNITY MEMBERS WITH BUILDINGS AND INFRASTRUCTURE PROJECTS THAT MEET THEIR NEEDS AND FULFIL THEIR REQUIREMENTS, IT HAS A MAJOR IMPACT ON THE ENVIRONMENT. The construction industry is a very large consumer of non-renewable resources. In addition, it is a significant source of waste and pollution of air and water as well as an important contributor to land dereliction. Furthermore, it is responsible for $50 \%$ of the material resources taken from nature, $40 \%$ of energy consumed and $50 \%$ of total waste generated. Towards saving the planet, it became crucial to stop the depletion of the natural capitals of the earth thorough developing creative and innovative solutions that achieve the objectives of present generations without compromising the ability of future generations to meet their own needs. This paper aims to investigate the role of Lean Principles (LPs) as an innovative approach for achieving sustainability in the Egyptian Construction Industry (ECI). Towards achieving this aim, a research methodology consisting of literature review, case studies and survey questionnaire, is designed to accomplish five objectives. Firstly, reviewing literature related to sustainability, (LPs) and highlighting their relationship as well as discussing the ability of (LPs) to achieve sustainability objectives. Secondly, presenting and analysing four case studies benefited from applying (LPs) to deliver sustainable projects. Thirdly, presenting and analysing results of a survey questionnaire directed to a sample of Egyptian Construction Firms (ECFs) to investigate their perception and application of (LPs) towards achieving sustainability objectives. Fourthly, developing a conceptual framework to promote the use of (LPs) as an innovative tool for achieving sustainability in (ECI). Finally, summarising research conclusions and recommendations useful to governmental authorities and construction professionals. 


\section{INTRODUCTION}

In terms of its activities and outputs, the $(\mathrm{Cl})$ represents an integral part of the social development and economic growth of both developed and developing countries (Field and Ofori, 1988; Mthalane et al., 2007). Socially, it aims to fulfil community needs through providing users with facilities for housing, education, culture, medication, business, leisure and entertainment. In addition, it constructs infrastructure projects comprising roads, water and electricity stations as well as telecommunication networks to enable these projects to perform their intended functions effectively (Friends of the Earth, 1995). Economically, Lowe (2003) stated that the value added of construction to the country's Gross Domestic Product (GDP) is in the range of $7 \%$ to $10 \%$ for highly developed economies and around $3 \%$ to $6 \%$ for underdeveloped economies. The construction outputs can be classified as a major component of investment and part of fixed capital; both are essential factors for a continuous economic growth. Furthermore, governments frequently use the $(\mathrm{Cl})$ as a driver to manage the local/national economy through increasing public expenditure to overcome the impact of recession and decrease the ratio of unemployment (Ball and Wood, 1995). On the other hand, the (CI) is criticised for having negative impacts on the environment. It is a very large consumer of non-renewable resources, a substantial source of waste and pollution to air and water. According to a study conducted by the U.S. Energy Information Administration (EIA) in 2011, the building sector consumes nearly half $(48.7 \%)$ of all energy produced in the United States. Globally, these percentages are estimated to be even greater (Architecture2030, 2011). Furthermore, the $(\mathrm{Cl})$ is responsible for generating most of the $\mathrm{CO}_{2}$ emission worldwide. The increasing concerns towards saving the environment, minimizing waste and using natural resources efficiently called for the $(\mathrm{Cl})$ to be more sustainable. Great improvements have been observed in manufacturing, especially lean automobile industry which uses about $50 \%$ of manufacturing space, human effort in factories, product development time and investments in tools (Koskela, 2004). These improvements were the result of the development and implementation of a new production philosophy called “Lean Production”. This philosophy aims to avoid waste of time, money, equipment, effort and improving value through employing and combining existing approaches such as Just in Time (JIT), Total Quality Management (TQM), time-based competition and concurrent engineering (Melles and Wamelink, 1993). Adopting the "Lean Production" philosophy is expected to bring a revolutionary change to the way of work in every industry. In construction, lean production has been adopted relatively quickly by contracting companies which are keen to reduce waste in their construction projects. Even if only a small fraction of the gains observed in manufacturing were realised in construction, the incentive to apply these concepts would be tremendous (Emmitt et al., 2004). Hence, this paper aims to investigate the role of (LPS) as an innovative approach for achieving sustainability in the (ECI).

\section{Research Methodology}

In order to achieve the aim of this research, a research methodology, consisting of literature review, case studies and survey questionnaire, is developed to accomplish five objectives.

1. Building a comprehensive background of the research topic by investigating the concepts of sustainability and (LPs), highlighting their relationship as well as discussing the ability of (LPs) to achieve sustainability objectives. This objective was achieved through conducting an in-depth literature review depending on textbooks, academic journals and professional magazines, conference and seminar proceedings, dissertations and theses, organisations and government publications as well as Internet and related websites.

2. Presenting and analysing four case studies to explore how (LPs) were applied to deliver sustainable projects. These cases were extracted from literature review and covered different project types in different countries including: residential complex in Brazil (Mota at al., 2005), industrial house builder in Sweden (Jansson et al., 2009), health care facility in Canada (Breen, 2011) and precast concrete production in Singapore (Wu and Low, 2010). Although there are many case studies about (LPs), the studied cases were selected as they are focused on applying (LPs) to achieve sustainability objectives. They were selected from different geographic areas, with diverse scope, nature, size and construction phases which helped accomplishing the study objectives and its argument. These case studies were analysed qualitatively through focusing on the application of (LPS) towards achieving the objectives of value, value stream, flow, pull and perfection.

3. Presenting and analysing results of a survey questionnaire conducted with a sample of (ECFs) to investigate their perception and application of (LPs) to achieve sustainability in construction projects. The survey questionnaire consisted of two sections. The first one aimed to collect general information about the surveyed organisations to form a profile of these firms, where the second section focused on investigating how (ECFs) perceive and apply (LPs) in order to deliver sustainable projects. The second section consisted of close ended (rating questions of 1 to 5 and multiple choice ones) and open ended questions. After the questionnaire was developed, it was essential to 
test its effectiveness and identify its problems. A preliminary test was conducted with colleagues who agreed to take the questionnaire and answer the questions as if they were received from someone unknown and go through the questionnaire again to point out any problem they noted with questions. After going over the responses of the preliminary test and making changes, the questionnaire was ready for formal testing (Baker, 1994; Czaja and Blair, 1996). Towards increasing the reliability and validity of the survey questionnaire, content validity was used through ensuring that the designed questionnaire was fully represent the underlying concepts of the subject being studied (Baker, 1994). In addition, a number of specialists were consulted to assess the extent to which the questions relate to the subject being investigated (Nachmias and Nachmias, 1996). Moreover, the same criteria used to analyse the case studies were also adopted when developing the survey questionnaire to help creating a correlation between the case studies and the survey questionnaire and their data analysis.

4. Developing a conceptual framework to promote the adoption and application of (LPs) as a powerful approach for achieving sustainability in the $(\mathrm{ECI})$.

5. Outlining research conclusions and recommendations useful to governmental authorities and construction professionals towards achieving sustainability through (LPs).

\section{Sustainability}

\section{Background and Definition}

Sustainability, in a broad sense, is the capacity to endure. All the needs of current and future generations for survival and well being depend largely on the natural environment, either in a direct or an indirect way. Sustainability aims to create and maintain the environmental, social and economic conditions that allow humans to exist with nature in "productive harmony" in the present and the future (USEPA, 2009). Sustainability has become a wide-ranging term that can be applied to almost every facet of life on Earth, ranging from a local to a global scale and over various time periods. The existence of more than 70 different definitions for sustainability (Holmberg and Sandbrook, 1992) highlighted its importance and illustrated the efforts made by different academic and practical disciplines to define and understand its implications to their fields. However, all definitions agree that it is of prime importance to consider the future of the planet and develop innovative ways to protect and enhance the Earth while satisfying various stakeholders' needs (Boyko et al., 2006). Scientific evidence showed that humanity is living unsustainably. This is obvious in the form of using nonrenewable resources, land dereliction, waste generation, water contamination, energy consumption, to name a few (Othman, 2010). Returning human use of natural resources to within sustainable limits will require a major collective effort. Since the 1980 s, sustainability has implied the integration of environmental, social and economic spheres to meet the needs of the present without compromising the ability of future generations to meet their own needs (World Commission on Environment and Development, 1987).

\section{Sustainability Aspects}

Sustainability has three main aspects: Environmental, Social and Economic. The interaction between these aspects generated three new aspects, namely: Social-Environmental, EnvironmentalEconomic and Economic-Social (see figure 1) (Rodriguez, et al., 2002).

> The environmental aspect of sustainability focuses on using natural resources efficiently; reducing waste, pollution, effluent generation and emissions to the environment. In addition, it aims to reduce the negative impact on human health, encourage the use of renewable raw materials as well as eliminate toxic substances.

- A social sustainable society is one that is fair and accomplishes social justice when it comes to distributing its resources within itself. It is a society that would not discriminate in the rights of its individuals based on their ethnicity, sex, religion, age or social background (BenzuJK, 2011). These rights, which lead to a quality standard of living, include religious rights, right to housing, right to social security, right to work, freedom of speech, right to travel and right to own property.

$\checkmark$ A society with a high population under the poverty line cannot achieve sustainability as this is accompanied by high unemployment rate, lack of education and low quality health care systems (Karlsson, 2009). An economically self sustaining society is one that is able to use the available resources efficiently to provide its individuals with their needs without reaching out for help from neighbouring societies or countries. Towards developing an economically sustainable society, public and private sector has to play a role towards investing in R\&D, offering employment opportunities, increasing productivity, escalating market share, adding value, creating new markets, reducing cost through improving efficiency and reducing energy as well as raw materials consumption.

6. The interaction between social and environmental aspects generated a new aspect which revolves around the right of all individuals to have a fair share of the natural resources of the environment at national and international levels. This ensures that these environmental resources are not exploited by a portion of the society leaving the rest of the society with needs that cannot be met by the remaining resources. 


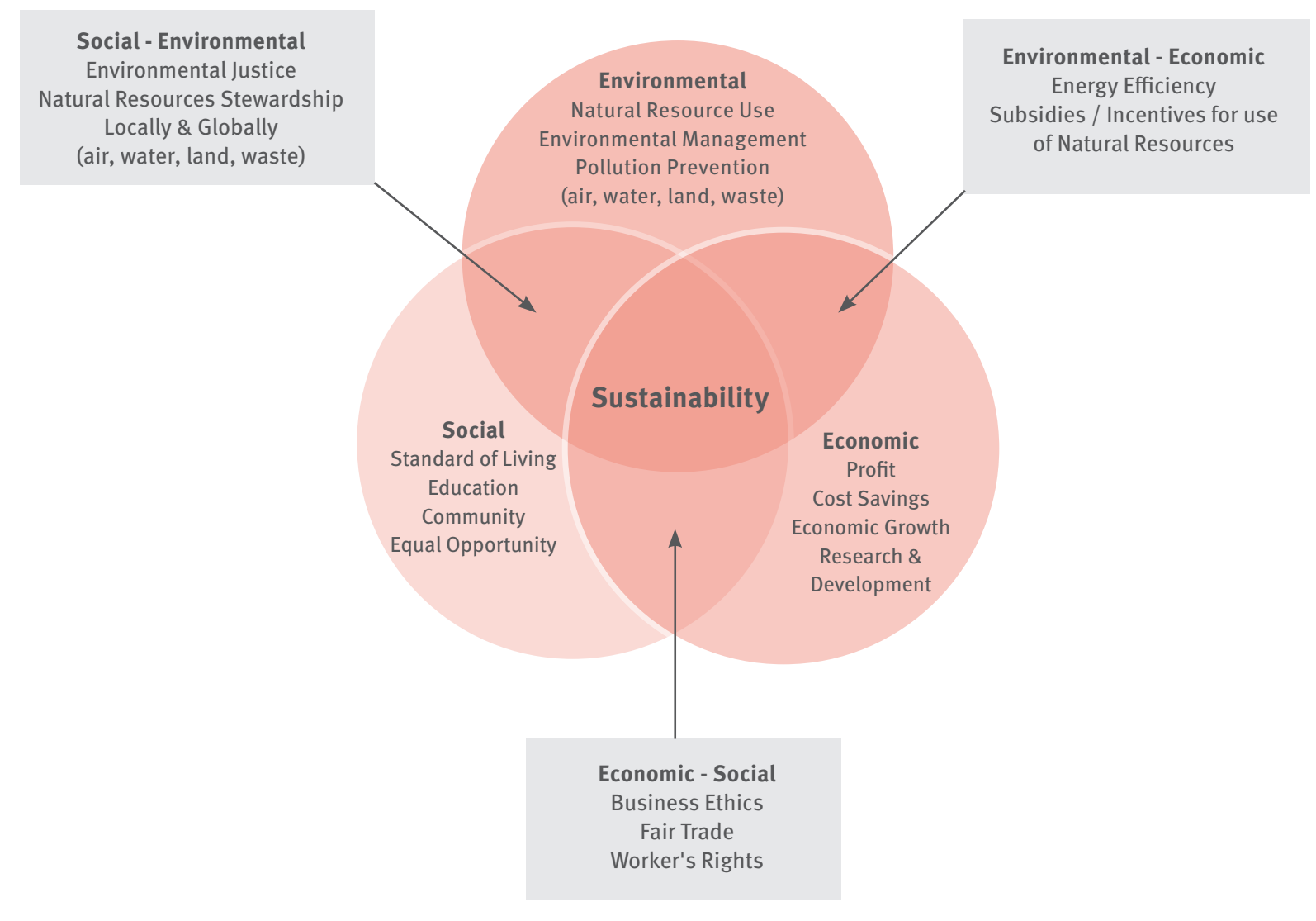

Figure 1. Aspects of Sustainability (Rodriguez, et al., 2002)

7. The economic-social aspect is the result of the interaction between economic and social aspects of sustainability. This aspect focuses on delivering economic sustainability without compromising society needs. This could be achieved through promoting business ethics, ensuring fair trade and preserving workers' rights.

8. The interaction between environmental and economic aspects of sustainability generated a new aspect which focuses on achieving environmental objectives of sustainability in an economic way. This requires the reduction of unnecessary costs and efficient use of energy and natural resources. In addition, it offers subsidies and incentives for encouraging research centres and construction organisations to develop creative solutions to achieve economical sustainable environment.

\section{Lean Principles}

By referring to Oxford dictionary (2010), "Lean" means thin, lack in richness and quantity, economical, sharp and low content. The main idea beyond the lean concept is to maximize customer's delivered value while minimizing waste. The lean theory can be summed up into five principles (Womack et al., 2003; Brookfield, 2004; Björnfot, 2006; Jansson, et al., 2009).

a) The Value principle focuses on identifying customer values and understating his/her requirements and constraints. In addition, it aims to define the internal and external factors that may affect the customer decision and find alternative solutions and most appropriate way to fulfil customer requirements at the most-cost effective manner. b) The Value stream principle maps the activities that, when done correctly and in the right order, will produce the product or service that achieve the customer's value. Activities can be classified as (1) non-value adding activities which should be eliminated; (2) supporting the value-adding activities that should be reduced as far as possible; and (3) value-adding activities which should be continuously improved.

c) The Flow principle aims to ensure that flow of work is steady and without interruption from one value adding or supporting activity to the next. Flow of work speeds the development process and hence, every effort should be made to eliminate obstacles that prevent such flow.

d) The Pull principle establishes to produce only, products that have been 


\begin{tabular}{|c|c|c|c|c|c|c|c|}
\hline \multirow[b]{2}{*}{ Lean Principles } & \multirow[b]{2}{*}{$\begin{array}{l}\text { Contributions of (LPs) Towards Achieving } \\
\text { Sustainability in the (CI) }\end{array}$} & \multicolumn{6}{|c|}{ Sustainability Aspects } \\
\hline & & 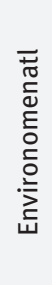 & 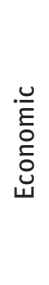 & $\begin{array}{l}\bar{\pi} \\
\stackrel{0}{0} \\
\text { in }\end{array}$ & 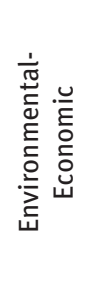 & 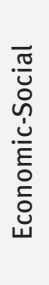 & 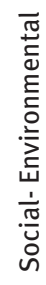 \\
\hline \multirow{5}{*}{ Value } & $\begin{array}{l}\text { Identifying the project customer and understanding his/ } \\
\text { her values, requirements and constraints. }\end{array}$ & $x$ & $\mathrm{X}$ & $x$ & & & \\
\hline & $\begin{array}{l}\text { Removing or reducing the influence of waste as it is } \\
\text { observed. }\end{array}$ & $x$ & $\mathrm{X}$ & & & & \\
\hline & $\begin{array}{l}\text { Identifying the impact of internal and external factors that } \\
\text { affect the customer decision and looking for alternative } \\
\text { solutions that adapt to changes without losing much time, } \\
\text { money or effort. }\end{array}$ & $x$ & $\mathrm{x}$ & $x$ & $\mathrm{x}$ & $x$ & $\mathrm{x}$ \\
\hline & $\begin{array}{l}\text { Maximizing the utility/outcome and benefit } \\
\text { of the project. }\end{array}$ & $x$ & $\mathrm{x}$ & $x$ & & & \\
\hline & $\begin{array}{l}\text { Deciding the most appropriate way to deliver the } \\
\text { customer's requirements. }\end{array}$ & $x$ & $\mathrm{X}$ & $x$ & $x$ & $x$ & $\mathrm{x}$ \\
\hline \multirow{4}{*}{ Value Stream } & $\begin{array}{l}\text { Defining all activities and recourses required for } \\
\text { production. }\end{array}$ & $x$ & $x$ & $\mathrm{X}$ & & & \\
\hline & $\begin{array}{l}\text { Optimising work content through work standardization, } \\
\text { repetition and preassembly and pre-fabrication. }\end{array}$ & & $\mathrm{X}$ & & $\mathrm{x}$ & & \\
\hline & Defining and locating key component suppliers. & & & & & $x$ & \\
\hline & $\begin{array}{l}\text { Organising and structuring job site materials, equipment, } \\
\text { tools, and resources for efficient project execution. }\end{array}$ & $x$ & $x$ & $x$ & $x$ & $x$ & $x$ \\
\hline \multirow{5}{*}{ Flow } & $\begin{array}{l}\text { Adopting the concept of work sequencing, crew balancing } \\
\text { and work in progress reduction. }\end{array}$ & $x$ & $x$ & $x$ & $x$ & $x$ & $x$ \\
\hline & $\begin{array}{l}\text { Reducing process cycle time through increasing work flow } \\
\text { and task organization. }\end{array}$ & & $\mathrm{X}$ & & $x$ & & \\
\hline & $\begin{array}{l}\text { Identifying key performance indicators and measuring } \\
\text { performance }\end{array}$ & & $X$ & & $x$ & & \\
\hline & $\begin{array}{l}\text { Posting relevant information concerning schedule, cost, } \\
\text { safety, and productivity about the job in a location that is } \\
\text { convenient for all managers and crafts. }\end{array}$ & & $\mathrm{X}$ & $x$ & $x$ & $\mathrm{X}$ & \\
\hline & $\begin{array}{l}\text { Incorporating all aspects of just-in-time delivery and } \\
\text { minimising materials' movement and relocation. }\end{array}$ & & $X$ & $x$ & $x$ & $x$ & \\
\hline \multirow{3}{*}{ Pull } & $\begin{array}{l}\text { Keeping the production system flexible and adaptable to } \\
\text { customer requirements and future changes. }\end{array}$ & $x$ & $x$ & $x$ & & & \\
\hline & $\begin{array}{l}\text { Exercising a conscious effort at shortening lead and cycle } \\
\text { times. }\end{array}$ & & $X$ & & $x$ & & \\
\hline & $\begin{array}{l}\text { Optimising work content through managing the impact of } \\
\text { design on the ability to achieve lean performance. }\end{array}$ & $x$ & $x$ & $x$ & & & \\
\hline
\end{tabular}




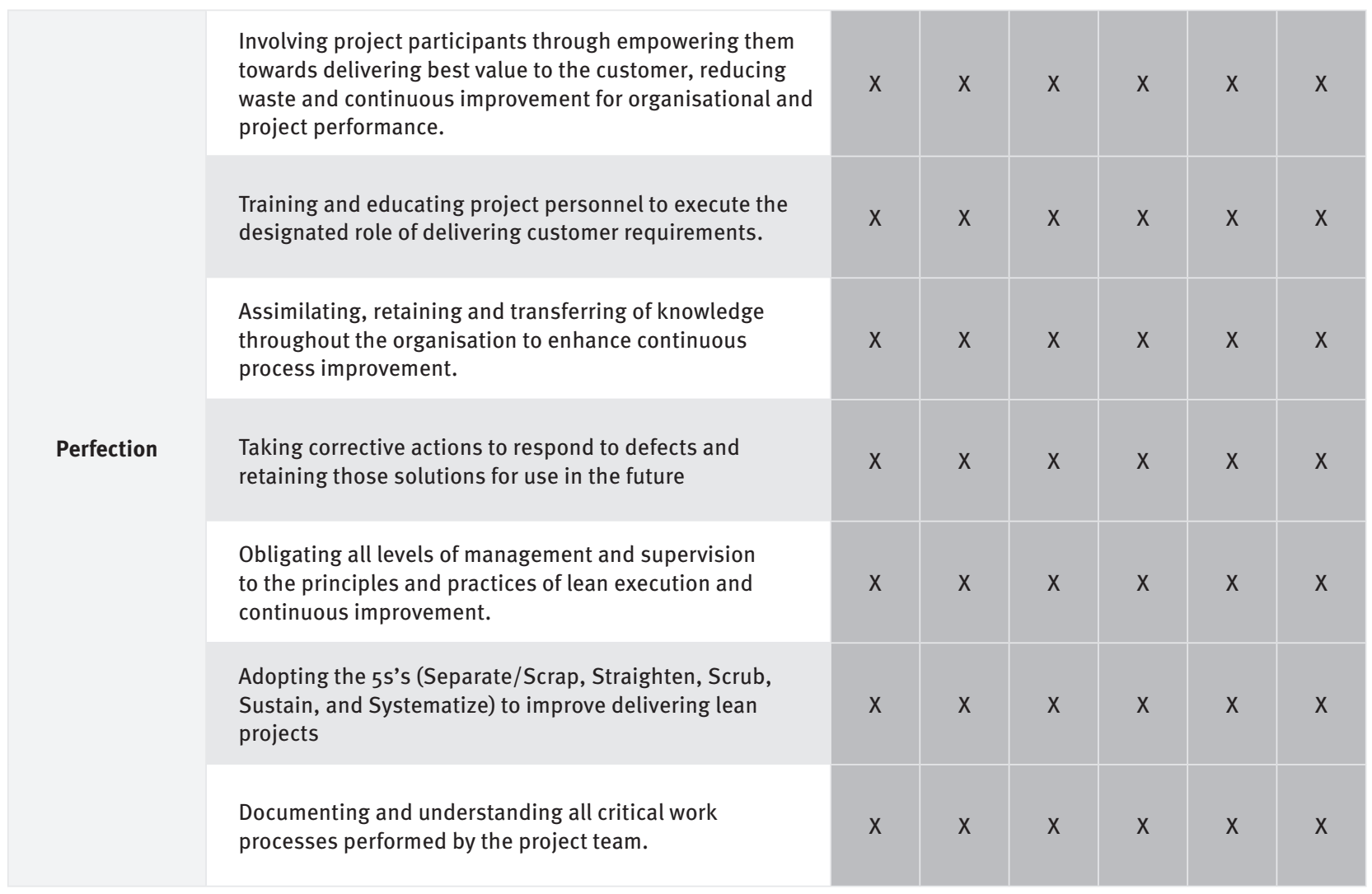

Table 1. Relationship and Role of (LPs) towards Achieving Sustainability in the (CI)

ordered. In non-lean organisations, work is pushed (i.e. the system produces outputs that are not required). Most lean services react to customer demand, adapt to his/her changes and so pull the work through the system.

e) The Perfection principle seeks to deliver exactly what the customer needs, when needed and at the most cost-effective manner. In a perfect process, every step is valuable-adding, capable (produces a good result every time), available (produces the desired output, not just the desired quality, every time), adequate (does not cause delay), flexible, and linked by continuous flow. If one of these factors fails some waste is produced. Perfection is a journey of continuous improvement and Lean organisations have to strive for perfection and develop strategies and procedures to set up quality controls and achieve perfection.

\section{The Relationship and Potentials of (LPs) towards Achieving Sustainability in Construction}

Current generations have the right to use the natural resources to achieve their goals and meet their needs. But using these resources inefficiently compromises the ability of future generations to meet their own needs. Therefore, there should be a trade-off between high comfort modern buildings versus resource consumption and environment degradation. The $(\mathrm{Cl})$ needs to be more sustainable and learn from other industries, such as manufacturing, that succeeded in maximising customer's values and minimising waste of resources, time and effort (Williams, 2000; Huovila and Koskela, 1998). This will encourage the (CI) to adopt (LPs) as a powerful approach to increase its efficiency and effectiveness. Analysis of the objectives of (LPs) and aspects of sustainability enabled the authors, to generate a matrix to explain the relationship between both disciplines and the role of (LPs) towards achieving sustainability in construction (see Table 1). For example, through applying the Value principle, proper identification of the project customer and understanding of his/her requirements helps the project team to deliver a product that satisfies the customer needs and reduces waste of materials, time or effort. In addition, this helps adapting to the internal factors (i.e. changing customer needs) and external factors (i.e. global economic recession) that affect the customer decision. Furthermore, the Value principle helps select the most appropriate way to deliver the customer requirements in a lean manner. Another example that explains of the role of (LPS) in achieving sustainability in construction is the Perfection principle. This principle focuses on empowering project teams, training them to execute the designated 


\begin{tabular}{|c|c|c|c|c|}
\hline Value & Value Stream & Flow & Pull & Perfection \\
\hline $\begin{array}{l}\text { Recognising that Time } \\
\text { is the most important } \\
\text { value to the customer. } \\
\text { Completing the project } \\
\text { one month earlier which } \\
\text { allowed the investor to } \\
\text { recover his investment } \\
\text { sooner than expected. }\end{array}$ & $\begin{array}{l}\text { Adopting the Line of } \\
\text { Balance (LOB) as a tool } \\
\text { to assure and maintain } \\
\text { continues work flow. } \\
\text { Motivating workers to } \\
\text { maintain and increase } \\
\text { their productivity rates } \\
\text { by providing incentives, } \\
\text { a win-win situation. }\end{array}$ & $\begin{array}{l}\text { Analysing work flow } \\
\text { activities according to } \\
\text { the construction rate } \\
\text { that was defined in the } \\
\text { traditional model. } \\
\text { Ensuring and } \\
\text { maintaining workflow } \\
\text { through moving workers } \\
\text { who completed a } \\
\text { certain task in a unit to } \\
\text { do the same task in the } \\
\text { following unit until the } \\
\text { last house is finished. } \\
\text { Ascertaining that all } \\
\text { materials needed to } \\
\text { complete a certain task } \\
\text { are available at the } \\
\text { work stations before the } \\
\text { workers shifts' begin. }\end{array}$ & $\begin{array}{l}\text { Reducing the waste } \\
\text { of environmental } \\
\text { resources as the firm } \\
\text { purchased only the } \\
\text { amount of materials } \\
\text { needed with minimal } \\
\text { leftover. } \\
\text { Developing a } \\
\text { procurement system } \\
\text { to alert the purchaser } \\
\text { when materials are } \\
\text { needed to ensure } \\
\text { that workflow is not } \\
\text { disturbed because of } \\
\text { deficiency of materials. }\end{array}$ & $\begin{array}{l}\text { Improving } \\
\text { organisational } \\
\text { performance and } \\
\text { finding solutions to } \\
\text { problems through } \\
\text { encouraging workers } \\
\text { to contribute their } \\
\text { opinions towards } \\
\text { meeting their needs } \\
\text { and increasing work } \\
\text { productivity as well as } \\
\text { reporting any errors and } \\
\text { obstacles may arise. }\end{array}$ \\
\hline
\end{tabular}

Table 2. Achieving Sustainability through (LPs) Application in the Residential Complex Project

role to deliver the customer's product. In addition, it helps improving performance through adopting the appropriate delivery techniques, assimilating, retaining and sharing knowledge, corrective actions and learned lessons. Furthermore, Perfection principle obligates all organisational levels to execute (LPs) and practices and strive for continuous improvement (Björnfot, 2006; Brookfield, 2004).

\section{Barriers to Achieving Sustainability in Existing Construction Practice}

The barriers to achieving sustainability in the currecnt construction practice are generally based on the nature of the $(\mathrm{Cl})$ and the culture of construction professionals and project participants. Basically, the existing $(\mathrm{Cl})$ is known for its chronic problems of fragmentation, low productivity, time and cost over-runs, poor safety, inferior working conditions and insufficient quality. In addition, the traditional procurement approaches commonly adopted in construction projects and the involvement of multitude of various project participants with diverse objectives, skills and interests tended to separate design from construction. This separation obstructs contractors from providing designers with constructive feedback and suggestions for design improvement, which ultimately hampers the development of sustainable construction (Othman, 2011; Forbes and Ahmed, 2011). Other barriers that hinder the inplmentation of sustainability in construction include (Tomkiewicz, 2011).

Market perception where no consumer demand for such a product. The $(\mathrm{Cl})$ is ultimately a business, and like any other, it aims to satisfy user demand. If there is no perceived demand, builders are not motivated to supply the product, unless perhaps, out of a desire for environmental philanthropy.

$>$ Information gaps, where there is lack of clarity of the direction or meaning of sustainability practices among academics and construction professionals.

- Lack of infrastructure, conflicts with permits, code compliance, appraisal and financing impede alternative sustainable construction methods.

- Lack of commitment of architects and contractors. Their aim is to reduce initial costs and make a fast profit. With limited architectural involvement, the integration of whole design practices and teaming required for a full implementation of sustainability becomes improbable. Additionally, it becomes difficult to develop a communal knowledge base, which extends beyond individual properties.

\section{Case Studies benefitted from Lean Principles Application in Construction}

This section presents a number of international best practice projects to explain the role of (LPs) towards delivering sustainable construction projects. 


\begin{tabular}{|c|c|c|c|c|}
\hline Value & Value Stream & Flow & Pull & Perfection \\
\hline $\begin{array}{l}\text { Establishing } \\
\text { organisational } \\
\text { strategies to focus on } \\
\text { meeting / exceeding } \\
\text { customer expectations. } \\
\text { Creating value for the } \\
\text { customers by handling } \\
\text { up to } 6 \text { projects in } \\
\text { parallel with flexibility } \\
\text { in the design process } \\
\text { (see Figure 2). } \\
\text { Adding value for the } \\
\text { design team through } \\
\text { conducting weekly } \\
\text { meetings and sharing } \\
\text { of information with } \\
\text { different project } \\
\text { participants. } \\
\text { Eliminating project } \\
\text { waste through } \\
\text { applying the concept of } \\
\text { constructability at early } \\
\text { stages of the project life } \\
\text { cycle. }\end{array}$ & $\begin{array}{l}\text { Focusing on the main } \\
\text { processes of the } \\
\text { project and reducing } \\
\text { effort invested in } \\
\text { standardising } \\
\text { sub-tasks. } \\
\text { Optimising time and } \\
\text { human resources in } \\
\text { activities that bring an } \\
\text { economic value to the } \\
\text { firm, and accordingly to } \\
\text { the society. }\end{array}$ & $\begin{array}{l}\text { Expediting flow of } \\
\text { information and } \\
\text { drawings in the design } \\
\text { process. } \\
\text { Reducing the number of } \\
\text { different software used } \\
\text { to save time and reduce } \\
\text { the amount of errors } \\
\text { and damaged files when } \\
\text { converting from one } \\
\text { format to the other. } \\
\text { Standardising } \\
\text { processes to eliminate } \\
\text { unnecessary workloads } \\
\text { and reduce the } \\
\text { amount of re-work } \\
\text { and materials as well } \\
\text { as energy consumed } \\
\text { during producing faulty } \\
\text { products due to errors. }\end{array}$ & $\begin{array}{l}\text { Facilitating the } \\
\text { production process and } \\
\text { making better use of } \\
\text { the short time allowed } \\
\text { for construction } \\
\text { ( } 4 \text { weeks) through } \\
\text { streamlining the } \\
\text { construction process } \\
\text { and information flow. } \\
\text { Using prefabrication } \\
\text { methods to reduce the } \\
\text { percentage of error } \\
\text { on site that could } \\
\text { result in economic } \\
\text { waste or a misuse } \\
\text { of environmental } \\
\text { resources. }\end{array}$ & $\begin{array}{l}\text { Using visual planning, } \\
\text { checklists, templates } \\
\text { and quality routines } \\
\text { for following up } \\
\text { the development of } \\
\text { projects. }\end{array}$ \\
\hline
\end{tabular}

Table 3. Achieving Sustainability through (LPs) Application in the Industrial House Builders

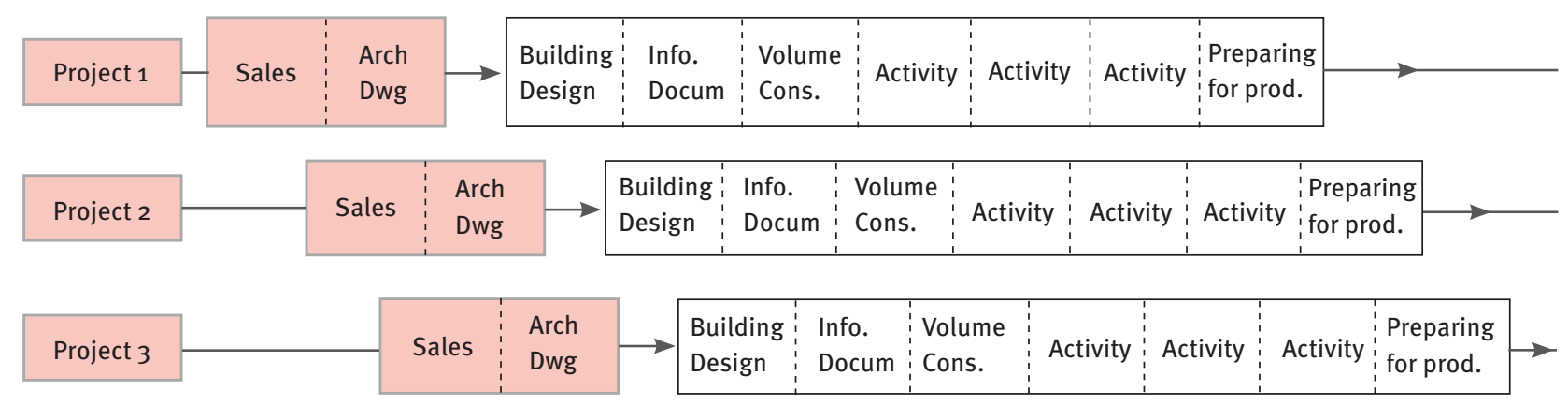

Timeline

Figure 2. Design process illustrated in project and process based work (Jansson et al., 2009)

Residential Complex, Fortaleza, Brazil

This is a residential complex project constructed in the urban area of Fortaleza, Brazil. It consisted of 18 houses financed by a private investor and was constructed and managed by a small-sized construction firm. Because of the gained benefits, the construction firm decided to go through the lean path after completed this project. The workers finished house (09) using the traditional construction techniques and then applied (LPs) to complete the rest of houses (Mota at al., 2005). Table (2) summarises the contributions of (LPs) towards achieving sustainability objectives in the residential complex project. Results of applying (LPs) helped achieving the objectives of sustainability aspects through increasing work productivity rate by $15.7 \%$ and reducing project duration by $12.5 \%$. In addition, they assisted accomplishing 


\begin{tabular}{|c|c|c|c|c|}
\hline Value & Value Stream & Flow & Pull & Perfection \\
\hline $\begin{array}{l}\text { Identifying the rate } \\
\text { of usage of each } \\
\text { department by } \\
\text { patients, medical and } \\
\text { administrative staff. } \\
\text { Deciding on the } \\
\text { equipment that are } \\
\text { urgently or most } \\
\text { needed. }\end{array}$ & $\begin{array}{l}\text { Identifying the activities } \\
\text { and transportations } \\
\text { within the centre that } \\
\text { cause the most delays } \\
\text { to the patient and waste } \\
\text { of time and materials. }\end{array}$ & $\begin{array}{l}\text { Minimising the } \\
\text { congestion in case } \\
\text { sensitive areas such as } \\
\text { emergency department) } \\
\text { through identifying } \\
\text { the most favourable } \\
\text { patterns for the } \\
\text { different users of the } \\
\text { facility to follow. } \\
\text { Shortening the distance } \\
\text { between the patient } \\
\text { and the designated area } \\
\text { and service provider. } \\
\text { Optimising the flow } \\
\text { of information, } \\
\text { equipment, supply, } \\
\text { processes and food. }\end{array}$ & $\begin{array}{l}\text { Attracting the customer } \\
\text { flow to certain areas } \\
\text { by creating land marks } \\
\text { within these areas to } \\
\text { reduced congestion and } \\
\text { enable more efficient } \\
\text { process execution to } \\
\text { take place. }\end{array}$ & $\begin{array}{l}\text { Ensuring design } \\
\text { effectiveness, not } \\
\text { only through creating } \\
\text { scaled models to the } \\
\text { different rooms in use } \\
\text { in each department, } \\
\text { but also by developing } \\
\text { a 1:1 scaled layout of } \\
\text { the final design to test } \\
\text { important features such } \\
\text { as line of sight, speed } \\
\text { of flow and efficiency of } \\
\text { delivering services to } \\
\text { the designated patient } \\
\text { (see figures } 3 \text { and } 4 \text { ). } \\
\text { Gathering customers' } \\
\text { feedback to enhance } \\
\text { the final layout design } \\
\text { even more. }\end{array}$ \\
\hline
\end{tabular}

Table 4. Achieving Sustainability through (LPs) Application in the Health Care Facility

the economic-social objectives of sustainability through using an incentive system to motivate workers achieve the goals determined by the firm and respond to the challenges defined by the project schedule. If this trend of efficiency continues in similar firms, the society is the one to benefit from the extra time, more available economic and environmental resources because these extra resources will be relocated to increase the individual's share.

\section{Industrial House Builders, Sweden}

Industrialized housing represents a growing market segment in the construction market in Sweden with an approximate market share of $15 \%$ (Björnfot, 2006). This project is of a Swedish timber housing firm specialized in student lodgings, hotels and senior dwellings. The buildings usually go as high as four stories. Their clients are mainly accommodating building societies, realestate clients and student associations. The customization and standardization degree is common within these projects. The firm employs 135 employees who are located at a single production site and they have an average annual turnover of 42 Million Euros (Jansson et al., 2009). Table (3) concludes the contributions of (LPs) towards achieving sustainability objectives in this project.

Through applying (LPs), the project succeeded in achieving a number of sustainability objectives. Firstly, handling parallel projects with flexibility during the design process as well as sharing information helped minimising waste and adding value to the customer and the design team. Secondly, by maintaining its processes and not investing in standardising sub-tasks, the firm saved its time and human resources efforts. Finally, using the pull strategy as the design duration is longer than the production time helped delivering needed products without generating waste or misuse of environmental resources.

Health Care Facility, British Columbia, Canada.

Provincial Health Service Authority (PHSA) plans, organises and evaluates specialty and general health care services in the province of British Columbia (BC), Canada. PHSA's projects include BC Women's Hospital and Health Centre. The authority has been implementing lean in its projects for almost 4 years. Recently, the current children's inpatient building, and BC Women's Neonatal Intensive Care Unit (NICU) and the Birthing Suite in the children's and women's health centre needed to be replaced. The replacement process of the children's inpatient centre process was planned to take place on three phases starting by demolishing and relocating the centre, building the new acute care centre and finally renovating the old centre (Breen, 2011). Table (4) concludes the contributions of (LPs) towards achieving sustainability objectives in this project.

This project relied on modelling a new design layout and testing its efficiency first hand by allowing the employees to simulate the flow of the building occupants. Being a health care centre, the flow of the building occupants through the centre is the main challenge faced while designing the 


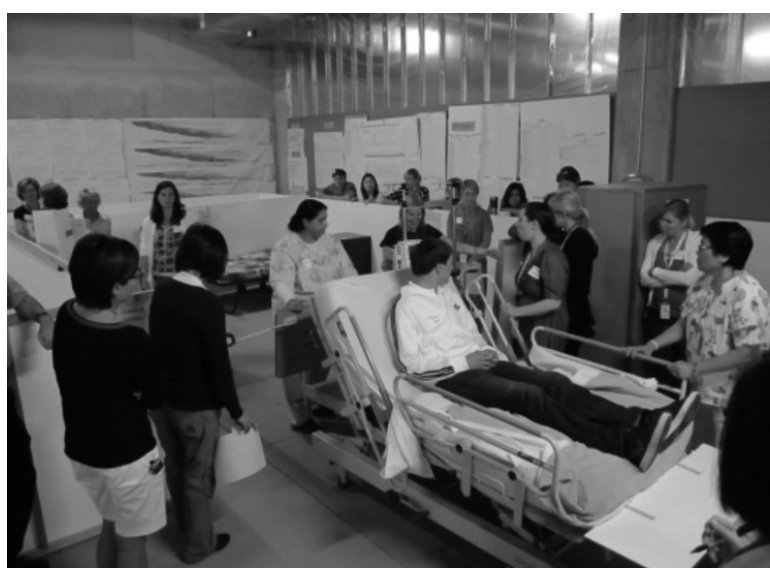

Figure 3. Mock ups scale 1:1 to the Inpatient and Oncology units (Breen, 2011)

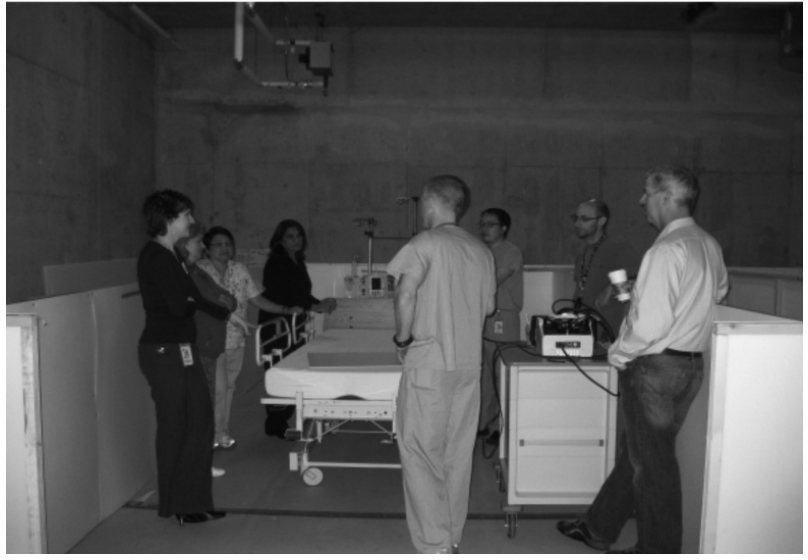

Figure 4. Mock ups scale 1:1 to the Inpatient Elevator (Breen, 2011)

\begin{tabular}{|c|c|c|c|c|}
\hline Value & Value Stream & Flow & Pull & Perfection \\
\hline $\begin{array}{l}\text { Reducing carbon } \\
\text { production during } \\
\text { precast concrete } \\
\text { production. } \\
\text { Improving assessment } \\
\text { of environmental } \\
\text { values. } \\
\text { Improving the value } \\
\text { chain of precast } \\
\text { concrete production. } \\
\text { Proper identification of } \\
\text { required material for } \\
\text { production to avoid re- } \\
\text { order and re-delivery of } \\
\text { correct materials. }\end{array}$ & $\begin{array}{l}\text { Eliminating waste } \\
\text { of time through } \\
\text { reorganising material } \\
\text { storage for production. } \\
\text { Considering alternative } \\
\text { transportation } \\
\text { methods to reduce lead } \\
\text { time and cost. }\end{array}$ & $\begin{array}{l}\text { Placing site layout plan } \\
\text { on the notice board for } \\
\text { information. } \\
\text { Maintaining long-term } \\
\text { contact to achieve } \\
\text { loyalty between } \\
\text { suppliers and pre- } \\
\text { casters. } \\
\text { Maintaining clear } \\
\text { identification of marks } \\
\text { and delivery notes in } \\
\text { the contract period. }\end{array}$ & $\begin{array}{l}\text { Eliminating the over } \\
\text { provision for material } \\
\text { storage. }\end{array}$ & $\begin{array}{l}\text { Reducing unplanned } \\
\text { changes in the } \\
\text { specification of precast } \\
\text { concrete production. } \\
\text { Making better use } \\
\text { of research in green } \\
\text { building materials. } \\
\text { Training incompetent } \\
\text { employees and } \\
\text { having proper written } \\
\text { production manual. } \\
\text { Enhancing employees } \\
\text { care towards avoiding } \\
\text { waste of finished } \\
\text { products and wrong } \\
\text { delivery. }\end{array}$ \\
\hline
\end{tabular}

Table 5. Achieving Sustainability through (LPs) Application in the Precast Concrete Production

circulation. Therefore, value stream mapping and flow presented guidelines to be followed to overcome theses circulation challenges (Breen, 2011).

Precast Concrete Production, Singapore.

Precast concrete products are widely adopted in the Singapore construction industry due to the rising demand from public housing projects. One of the solutions to reduce construction duration and improve efficiency would be to use precast concrete products which are able to provide a cost-effective way of carrying out "system building" types of construction projects. Table (5) summarises the results of applying (LPs) towards improving the sustainability of precast concrete production practices (Wu and Low, 2010).

Through applying (LPs), it was possible to reduce costs and eliminate waste through improving the efficiency of the process, improve quality and focus on adding value activities for customer satisfaction and ensures health and safety standards for workers through providing information on the information board as well as reduce carbon emission. In addition, (LPs) application helped improving training program for supporting sustainable operations and efficient use of raw materials and resources.

\section{Field Study}

This section presents the results of a field study conducted, by the authors, 
through a survey questionnaire to investigate the perception and application of (LPs) as an approach for achieving sustainability in the (ECI). The questionnaire sample was selected from the list of 14000 contractors registered with the Egyptian Federation for Construction and Building Contractors (EFCBC, 2012). To get a representative and reasonable sample size that supports the research findings, the following equations were used. Equation (1) is applied to compute the initial sample size. Since the population is finite (less than 50,000), Equation (2) is used to compute the new sample size (Johnson and Bhattacharyya, 2009; Freedman et al., 2007).

$S S=Z 2$ * $(p)$ * $(1-p) / c 2$

Equation (1)

New SS = SS / (1+ (SS-1) $/$ Pop Equation (2)

Where:

SS $=$ Sample Size

$\mathrm{Z} \quad=\quad$ Z-values for confi-

dence levels are $(1.645$ for $90 \%$ confidence level, 1.96 for $95 \%$ confidence level and $\mathbf{2 . 5 7 6}$ for $99 \%$ confidence level)

$\mathrm{p} \quad=\quad$ percentage picking $\mathrm{a}$ choice, expressed as decimal (0.5 used for sample size needed)

c = confidence interval, expressed as decimal (e.g., .08 $= \pm 8$ )

Pop = Population

In our case:

$\mathrm{SS}=(1.96) 2$ * $(0.5) *(1-0.5) /(0.08) 2$ $=150.063$

New SS $=150.063 /(1+(150.063-1) /$ $14000)=148.48 \approx 148$

The same result was confirmed by the sample calculator (The Survey System, 2012), through using a confidence level of (95\%) and confidence interval of (8) when combined with a population of (14000) contracting

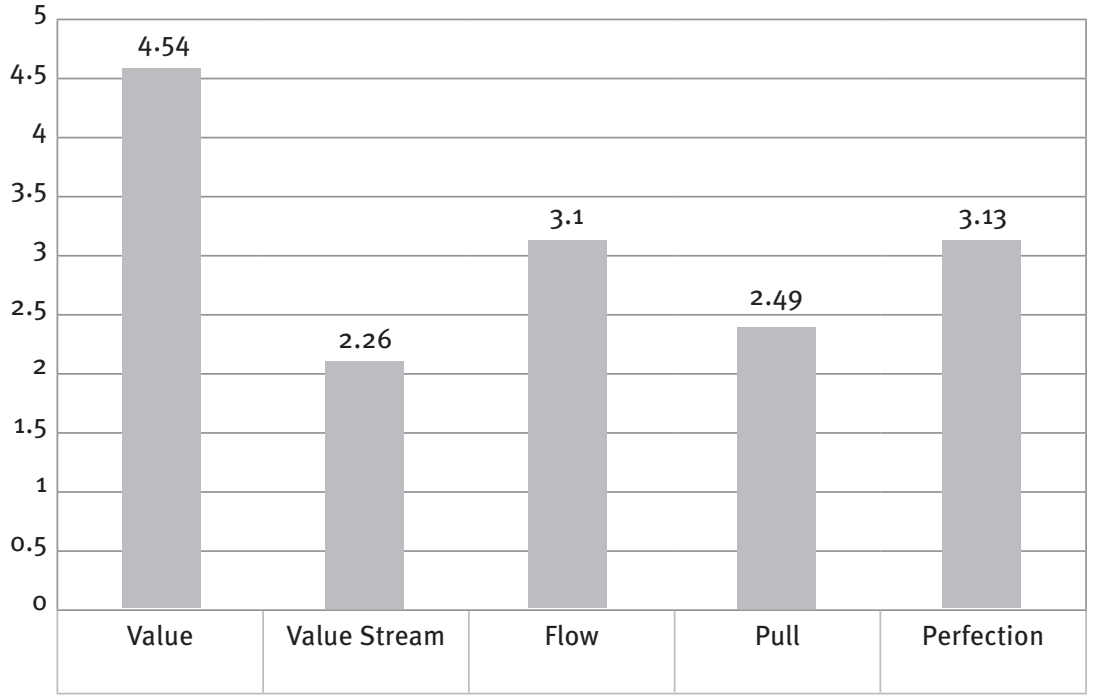

Figure 5. Average Areas of (LPs) Applications in Construction

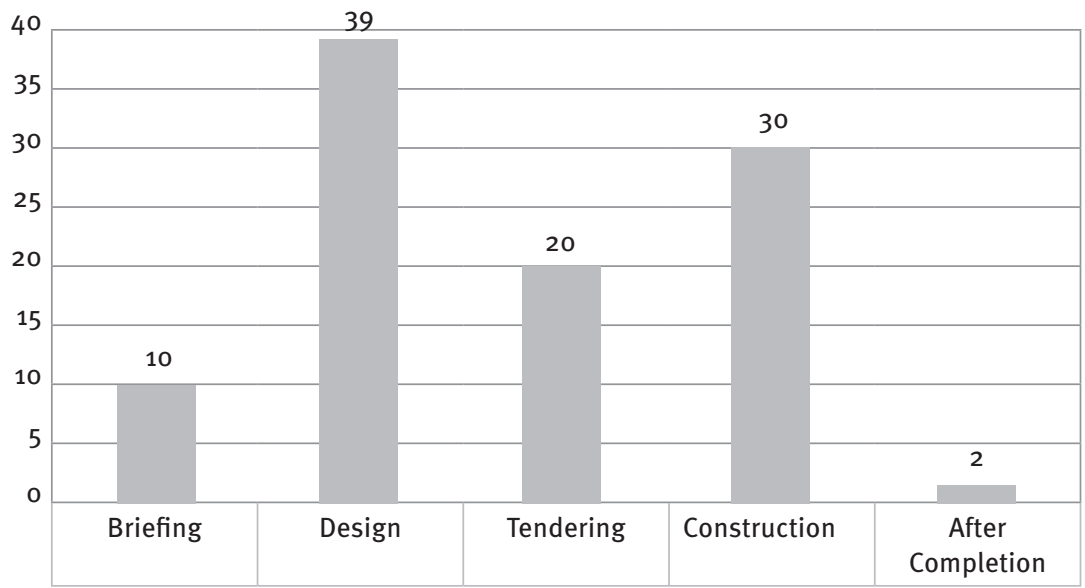

Figure 6. Responses of the Phases of Applying (LPs) troughout the Project Life

companies yielded a suitable sample size of (148) participants. This approach is adopted by many researchers to avoid using manual and complicated sample size formulas. Sample size calculator is an online simple and accurate tool designed to analyse sample size through giving researchers different options to select from (Bridges, 2013). These firms were contacted and the questionnaire was delivered to them either by hand, mail or e-mail. Out of 148 questionnaires were sent, only 67 were completed and returned, providing a response rate of $45.27 \%$.
According to Babbie (1992) as a rule of thumb $50 \%$ is adequate while, McNeil and Chapman (2005); Saunders et al., (2003); Gillham (2000); Tashakkori and Teddlie (1998); Fellows and Liu (1997) state that 30-40 per cent is acceptable because of the fact that few people respond to questionnaires.

\section{Data Analysis of the Survey}

Questionnaire

Perception and Application of (LPs) in Construction Projects

39 out of 67 respondents to the questionnaire, which represent 
(58.2\%), stated that they perceive the concept and apply it in their projects (by adding value to customers while eliminating waste) without knowing that this practice is called Lean. On the other hand, the remaining companies mentioned that they have not adopted (LPs) approach in their projects.

\section{Area of Focus when Applying (LPs) in Construction Projects}

Figure (5) shows the responses of the surveyed firms to rate the areas of their focus when applying (LPs) in construction projects, namely: Value, Value Stream, Flow, Pull and Perfection. These areas were used to analyse case studies. Results showed that the concept of "Value" received (4.54) out of (5) which ensures that proper understanding of clients / customers value system is paramount towards delivering their requirements in a lean manner. This is followed by "Perfection" and "Flow" with an average of (3.13) and (3.1) out of (5) respectively, which indicates that continuous improvement and built-inquality as well as flow of information and materials are key elements towards using (LPs) to achieve sustainability in construction projects.

\section{The Internal Governance towards (LPs) Adoption and Application in (ECFs)}

Towards investigating the internal governance of the surveyed firms towards adopting and applying (LPs), respondents were asked to select between "internal governance" as the firm's vision for the future, "mission statement", "lean objectives" or "others". Responses are:

> 20 out of 39 respondents, which represent $(51.28 \%)$, stated that "mission statement" was the most popular form of governance that their firms used. "Mission statement" of these firms focuses on achieving customer satisfaction through delivering products that best meet or exceed his/her expectations at the most cost effective manner.
10 out of 39 respondents, which represent ( $25.64 \%$ ), mentioned that "lean objectives" were ranked second as the firm governance. Firms believe that "lean objectives" are the right thing that has to be done towards saving the environment, prospering economy and serving the society.

9 companies out of 39 , which represent (23.07\%), stated that the "vision of their companies" in the future is the internal governance for (LPs) adoption and application. Companies consider (LPs) as a competitive advantage tool that will increase their market share in the future and assist the firm to remain competitive in the market.

\section{Phases of (LPs) Application in Construction Projects}

Figure (6) summarises the responses of the surveyed firms to investigate the different phases of applying (LPS) in construction projects, namely: Briefing, Design, Tendering, Construction and After Practical Completion phase.
Results showed that all surveyed firms adopted (LPs) towards achieving sustainability during the design phase as decisions taken during this phase have important impact on the constructed facility throughout its life cycle. In addition, 30 out of 39 firms, which represent $(76.92 \%)$, adopted (LPs) during the construction phase as many of lean activities are related to site construction such as material provision and storage as well as site layout and workers movement and the application of lean principles in this phase has positive impacts.

\section{The Potentials and Constraints of Adopting and Applying (LPs) in (ECI)} Responses of the questionnaire with regard to the reasons that encouraged (ECFs) to adopt and apply (LPs) in construction are as follows:

$\checkmark 20$ out of 39 respondents, which represent $(\% 51.28)$, stated that (LPs) are used because they are good marketing tool; improve productivity,

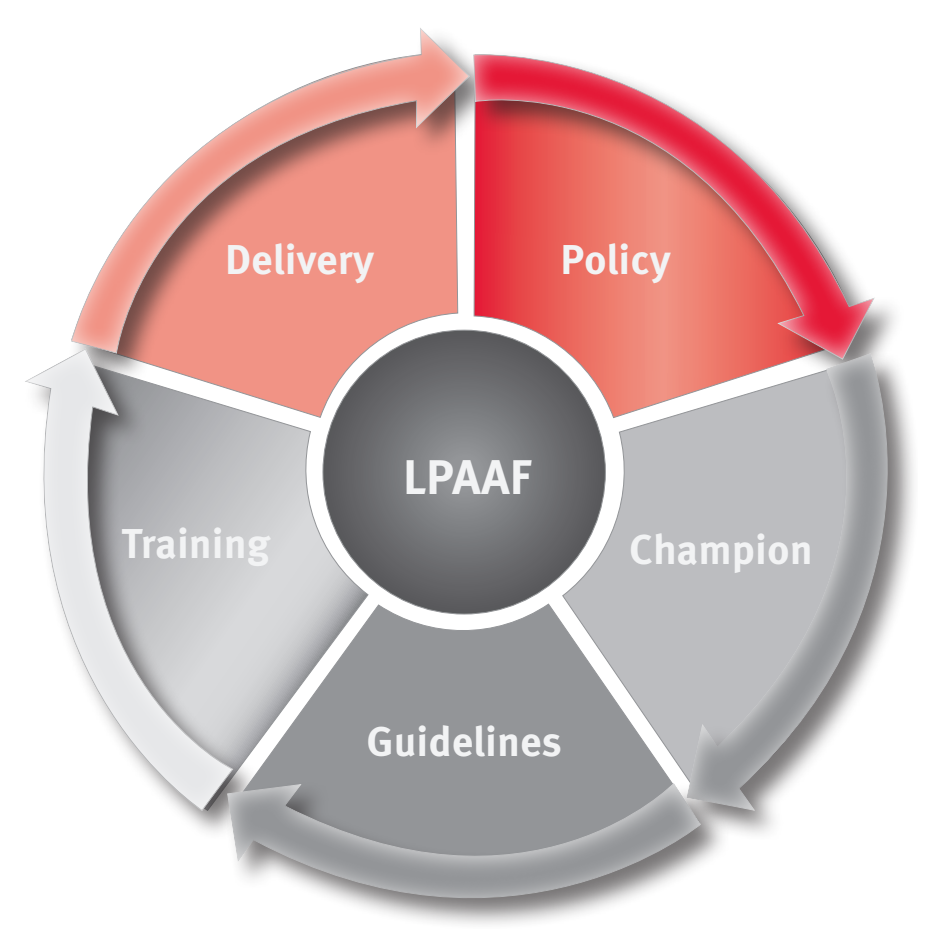

Figure 7. Components of the Lean Principles Adoption and Application Framework 
increase customer satisfaction and reduce waste of time and effort.

19 respondents highlighted that (LPs) helped them minimise project cost, add more value to the customer, increase firms' performance, improve flow of information and facilitate communication.

The 28 firms that did not adopt (LPs) have identified the reasons that hindered the adoption and application of (LPs) as:

- It is not mandatory requirements either by customers, construction industry or governmental authorities.

- Lack of knowledge and perception of the lean concept. No training programmes are offered to educate construction professionals about the new concept either at undergraduate, postgraduate or industry levels. Respondents mentioned that (LPs) are not dealt with as a strategic objective by firm's management.

- Time and money constraints. Respondents believe that new concepts such as (LPs) are expensive and time consuming. Firms prefer to use tested and successfully proofed methods rather than applying new concepts.

- There is no formal framework to integrate (LPs) in (ECFs).

\section{A Conceptual Framework for Promoting the Adoption and Application of (LPs) in Construction Firms}

\section{Framework Rationale and \\ Development}

Results of literature review, case studies and field study revealed that (LPs) are powerful approach to achieve sustainability in construction projects. On the other hand, it is of prime importance to have a formal framework to facilitate the adoption and application of (LPs) in construction firms and establish the strategies that support its success. In order to ensure the successful implementation of (LPs), construction firms should be Lean oriented. A lean firm understands customer value and focuses its key processes to continuously increase it. The ultimate goal is to provide perfect value to the customer through a perfect value creation process that has minimum or zero waste. This necessitates that the whole firm should be involved in the lean process development. The Lean Principles Adoption and Application Framework (LPAAF) outlines and relates the components which support (LPs) application in construction firms and serves as a guide that can be modified to meet organisational needs.

\section{Components of the Framework}

The proposed framework consists of five elements, namely: Policy, Champion, Guidelines, Training and Deliver (see Figure 7).

\section{Policy}

The Firm's policy should establish the need to adopt and apply (LPs) and justify what benefits this approach expects to generate. For instance, these benefits could be delivering sustainable projects, maintain firm's competitiveness or improve communication and information flow. The policy has to provide clear guidance on when (LPs) have to be integrated throughout the project life cycle and what are the resources needed. The policy should state, in broad terms, to which areas of the business (LPs) are to be applied and provide guidance on the scale of that application. It should also state whether the firm intends to generate its own internal delivery capability or rely on buying in the expertise when needed or a mixture of the two. It should set out a timescale within which they expect to embed the practice of (LPs) into the firm's culture.

\section{Champion}

Once the firm's policy has been stated, it is essential to appoint an individual to implement this policy. The appointed individual will be designated as the Head of Lean Principles Programme (HLPP). Senior management has to form a small steering group, which represents the various parts of the firm, to whom the (HLPP) will report and discuss progress. Members of the steering group should report to the firm's board of directors. The (HLPP) has to possess a sound understanding of (LPS) and their application. In addition, s/ he should draw up a plan setting out how the policy will be implemented and corrective actions to be taken in case the procedures deviated from the developed plan.

\section{Guidelines}

The (HLPP) is responsible for setting out guidelines that describe the types of study that should be conducted at strategic, programme, project and operational levels. The guidelines should outline the process to follow, list suitable techniques to be used; provide guidance on who should be involved and the level of competence and experience of the leader who will lead the studies of implementing (LPs). The guidelines should provide also, the basis for delivering repeatable processes but not be so prescriptive as to stifle individual interpretation and innovation.

\section{Training}

Training provision is the first step towards achieving the plan of adopting and applying (LPs) in construction firms. It has to be shaped by the policy either by using internal or external expertise. If the firm plans to use only external expertise due to lack of internal resources for instance, the training programme will be focused on building up an awareness of (LPs) and their benefits at all levels of the firm. This is essential to gain support throughout the firm and to build up a collaborative culture. If it is intended to build up internal delivery expertise, it is essential to train up or employ internal study leaders with competent delivery skills levels. To ensure 
that the training programme is effective, it should be accredited by a competent organisation and lead to a professional qualification. Both the awareness and the practitioner training courses should align with the firm's policy and its approach to doing business.

\section{Delivery}

The second step of the plan is the delivery of the services themselves within the designated projects using the appropriate techniques. The (HLPP) should gather feedback from all participants, in addition to the formal reports to build up an information base and learn from experience. The lessons learned have to be incorporated into the training programme and shared between employees to ensure that the quality of service is continuously improved.

\section{Strategies for Successful} implementation of the Framework For the (LPAAF) to be successfully adopted and implemented in construction firms, certain strategies should be in place as follows:

> Clear identification and visible senior management support for (LPs) adoption and application.

- Explicit policies which are clearly communicated to all employees.

$\checkmark$ Creating a culture that supports and understands the concepts of maximising value and minimizing waste.

- Fully embedded management processes which are consistently and rigorously applied and are clearly linked to the achievement of (LPs) objectives.

Effective implementation of plans and regular reviews to ensure that the benefits of (LPs) are realised and lessons are learned for future programmes.

\section{Framework Limitations and}

\section{Potentials}

The effective application of the framework depends to a large extent on the encouragement of the top management in construction firms to adopt (LPs) as an approach to achieve sustainability in construction. If the top management does not have the desire and tended not to use the framework, then its adoption will be limited. In addition, the application of the framework is a long-term strategy to improve the traditional culture and methods of doing work in construction, and hence it could be resisted by some sectors of the $(\mathrm{Cl})$. For this reason, it is essential that the benefits of the framework be clearly presented to top management of construction firms in order to get them convinced with the role, which the framework could play in improving their performance and achieving sustainability in their projects. This will increase the opportunities for adopting the framework. Although the developed framework is a conceptual one and not validated due to the limited resources of the authors and time needed, it provides construction firms with detailed components that explain how to adopt and apply (LPs) in their projects.

\section{Conclusions and Recommendations}

After reviewing the fundamentals of (LPs), sustainability and investigating a number of case studies that benefitted from (LPs) towards delivering sustainable products, and keeping in mind the results of the field study, the research come to the following conclusions and recommendations:

The $(\mathrm{Cl})$ plays a significant role towards social and economic development at national and international levels. However, it has negative impact on the environment being a source of waste, energy consumption, land dereliction and pollution. This called for the $(\mathrm{Cl})$ to be more sustainable through using natural resources in an efficient way to enable current generations to meet their needs without compromising future generations from achieving their own needs.

(LPs) have proven to be a powerful tool to minimize waste and adding better value to customers in the manufacturing industry. The application of (LPs) in construction helps defining customer value, eliminating waste, improving flow of work and information and increasing organisational perfection.

Results of the field study showed that (LPs) are generally perceived and applied in a number of (ECFs) without realising that these practices are called lean. These concepts are used mainly in the design phase and construction phases. On the other hand, other firms stated that (LPs) were not adopted due to a number of reasons such as it is not mandatory requirement, lack of knowledge, time and cost constraints as well as the absence of formal frameworks to integrate (LPs) in (ECFs).

This led to the following recommendations:

- Recommendations to Governmental authorities in Egypt

- Governmental authorities responsible for construction and urban development are advised to promote the use (LPs) as a strategic approach towards achieving sustainability in construction.

- Issuing and enforcing legislations to facilitate the adoption of (LPs) in design and construction firms as well as developing incentive programmes to attract and acknowledge the firms that adopt (LPs) and succeeded in delivering sustainable projects.

- Integrating (LPs) in architectural and construction education at undergraduate and graduate studies to generate graduates who understand the concept and its benefits and hence, apply it in their projects.

- More seminars, conferences, training programmes that are concerned 
with (LPs) and sustainability should be organised on regular bases in an effort to educate the industry players and share research findings with construction professionals.

Recommendations to Egyptian Construction Firms

- (ECFs) are advised to integrate lean philosophy in their business development strategy. This requires establishing the need to adopt and apply (LPs) and justifying what benefits that this approach could generate. In addition, it necessitates senior management support and provides clear guidance on when (LPs) have to be integrated throughout the project life cycle and what are the resources needed. The policy should state, in broad terms, to which areas of the business (LPs) are to be applied and provide guidance on the scale of that application.

- Offering training programmes to enhance the skills of employees and increase their capabilities towards perceiving and applying (LPs). (ECFs) have to decide whether to generate its own internal delivery capability or rely on buying in the expertise when needed or a mixture of the two. It should set out a timescale within which they expect to embed the practice of (LPs) into the firm's culture.

- Focus should be directed towards applying (LPS) during the briefing and after practical completion stages being got the lowest average amongst the different stages of the project life cycle. These are two essential milestones for delivering sustainable projects. At the briefing stage, important decisions are made which affect the performance of the project throughout its life cycle, where feedback gained from the after practical completion stage help improving design decisions taken in earlier stages.

- Validating and applying the proposed framework will help construction firms adopt (LPs) to achieve sustainability in construction projects.

\section{References}

Architecture2030. (2011). Buildings are the problem. [Online]. Available from: Architecture 2030: http://architecture2030. org/the_problem/buildings_problem_why (accessed 29 May 2012).

Babbie, E. (1992). The practice of social research. Belmont, CA: Wadsworth Publishing.

Baker, T. L. (1994) Doing Social Research. 2nd ed. New York: McGraw-Hill Inc.

Ball, M. and Wood, A. (1995). How many Jobs does Construction Expenditure Generate, Construction Management and Economics, 13, 307-318.

BenzuJK. (2011). Three aspects of Sustainable Environmental Architecture.

[Online]. Available from: http://www. architecture-student.com/sustainabledesign/three-aspects-of-sustainableenvironmental-architecture/ (accessed 29 May 2012).

Björnfot, A. (2006). An Exploration of Lean Thinking for Multi-Storey Timber Housing

Construction: Contemporary Swedish Practices and Future Opportunities. Luleå University of Technology, Luleå, Sweden.

Boyko, C.T., Cooper, R., Davey, C.L. and Wootton, A.B. (2006). Addressing sustainability early in the urban design process', in International Journal of Management of Environmental Quality, 17(6), 689-706.

Breen, B. (2011). Applying Lean Thinking and Principles in Building Design. Provincial Health Services Authority, British Columbia, Canada.

Bridges (2013). Bringing Research in Diabetes to Global Environment and systems.

Calculating Sample Size Using On-line Power Calculators: Examples, http:// www.idf.org/files/BRIDGES-sample-sizecalculation-and-example-of-budget.pdf (Accessed 4 February 2013).

Brookfield, E. E. (2004). The Architectural Technologist's Role in Linking Lean Design with Lean Construction. Elsinore.

Czaja, R. and Blair, J. (1996) Designing Surveys:
A Guide to Decisions and

Procedures. London: Pine Forge Press.

EFCBC. (2012). Egyptian Federation for Construction and Building Contractors.

http://www.tasheed.org/english/eng_home.

aspx (accessed 29 May 2012).

Emmitt, S., Sander, D. And Christoffersen, A.K. (2004). Implementing Value Through Design Management. IGLC 2004, Helsingor.

Fellows, R. and Liu, A. (1997). Research methods for construction. Oxford: Blackwell

Publisher Ltd.

Field, B. and Ofori, G. (1988). Construction and economic development - a case study in Third World Planning Review, 10(1), 41-50.

Forbes, L. H., and Ahmed, S. M. (2011). Modern Construction: Lean Project Delivery and Integrated Practices. Taylor and Francis Group, Oxon, UK.

Freedman, D. A., Pisani, R. and Purves, R.A. (2007). Statistics. 4th ed. W. W. Norton, Inc. New York (2007).

Friends of the Earth. (1995). Prescription for Change: Health and the Environment, Brussels, Friend of the Earth.

Gillham, B. (2000). Developing a questionnaire. London: Continuum.

Holmberg, J. and Sandbrook, R. (1992). Sustainable development: What is to be done?', in J. Holmberg (ed), Policies for a Small Planet, London, Earthscan.

Huovila, P. and Koskela, L. (1998). Contribution of the Principles of Lean

Construction to Meet the Challenges of Sustainable Development. Proceedings IGLC'98

Jansson, G., Söderholm, E., and Johnsson, H. (2009). Design Process Organisation at Industrial House Builders. Luleå, Sweden: Luleå University of Technology, Division of Structural Engineering.

Johnson, R.A and Bhattacharyya, G.K. (2009). Statistics: Principles and Methods. 6th Ed. John Wiley and Sons.

Karlsson, I. (2009). Social and economic aspects of sustainable development.

Uppsala University, Sweden: The Baltic University Programme, Uppsala Centre for 
Sustainable Development.

Koskela, L. (2004). Moving-on - Beyond Lean thinking. Lean Construction Journal,

1(1), 24-37.

Lowe, J.L. (2003). Construction Economics. [Online]. available from:

www.callnetuk.come/home/johnlowe 70/ (Accessed 15 August 2012)

McNeil, P. And Chapman, S. (2005). Research methods. 3rd Edition. Routledge:

Taylor \& Francis Group.

Melles, B. and Wamelink, J. W. F. (1993). Production Control in Construction. Delft University Press, Delft, The Netherlands.

Mota, B. P., Mota, R. R., and Alves, T. d. (2005) Implementing Lean Construction

Concepts in a Residential Project. Brazil: Federal University of Ceará.

Mthalane, D., Othman, A.A.E. and Pearl, R.G. (2007). The economic and social

impacts of site accidents on the South African society', in J.J.P. Verster and H.J. Marx (eds), in Proceedings of the 5 th Post Graduate Conference on Construction Industry Development, Bloemfontein, South Africa, March 2008, 1-10.

Nachmias, C. and Nachmias, D. (1996). Research Methods in the Social Sciences. 5th ed. London: Arnold.

Othman, A.A.E. (2010) Incorporating Innovation and Sustainability for Achieving Competitive Advantage in Construction. In: Wallis, I., Bilan, L., Smith, M. and Kazi, A.S. (eds.) Industrialised, Integrated, Intelligent sustainable Construction $\mathrm{I}_{3} \mathrm{CON}$ Handbook2, pp. 13-42.

Othman, A.A.E. (2011). Culture Change in Construction: A Novel Approach for

Achieving Lean Construction Objectives in Construction Projects. Proceedings of the 6nd Built Environment Conference, Johannesburg, South Africa, 31 July - 2 August 2011, pp. 537-553. ISBN number: 978-0-86970-713-5

Oxford Dictionary (2010). [Online]. Available from: http://oxforddictionaries.com (Accessed 12 April 2011).

Rodriguez, S., Roman, M., Sturhahn, S., and Terry, E. (2002). Sustainability

Assessment and Reporting for the University of Michigan's Ann Arbor Campus. Master's Thesis . University of Michigan: Ann Arbor: 1-396.

Saunders, M., Lewis, P. and Thornhill, A. (2003). Research methods for business students. Harlow: Prentice Hall.

Tashakkori, A. and Teddlie, C. 1998. Mixed methodology, combining qualitative \& quantitative approaches. Thousand Oaks, CA: Sage Publications.

The Survey System. (2009). Sample Size Calculator. Retrieved April 2009. [Online]. Available from: http://www.surveysystem.com

Tomkiewicz, H. S. (2011). Barriers to Implementation of Sustainable Construction

Practices in the Homebuilding Industry: A Case Study of Rochester, NY" (2011). [Online]. Available from: http:// digitalcommons.unl.edu/archthesis/121 (Accessed 15 August 2012).

USEPA. (2009). Basic Information. Retrieved March 19, 2012, from The United States Environmental Protection Agency (USEPA) [Online]. Available from:

http://www.epa.gov/sustainability/basicinfo. htm (accessed 29 May 2012).

Williams, R. A. (2000). Environmental Planning For Sustainable Urban Development.

Caribbean Water and Wastewater Association - 9th Annual Conference \& Exhibition. Chaguaramas, Trinidad.

Womack, J., Jones, D., and Roos, D. (2003). The Machine That Changed The World.

World Commission on Environment and Development (1987). Our Common Future, Oxford, Oxford University Press.

Wu, P. and Low S.P. (2010). Lean production, value chain and sustainability in precast concrete factory - a case study in Singapore. Lean Construction Journal, 92-109. 